\title{
IMPROVEMENT OF CORN PRODUCTIVITY BY BACTERIAL INOCULATION, N MINERAL AND ORGANIC FERTILIZATION
}

\author{
Mehasen, S.A.S. * and M.A. Ahmed** \\ *Agron. Dept., Fac. of Agric., Moshtohor, Benha Univ., Egypt \\ ** Agron. Dept., Fac. of Nasser Agric Science, Aden Univ., Yemen
}

\section{ABSTRACT}

The study was carried out at the Agricultural Research and Experimental Center of the Faculty of Agriculture, Moshtohor, Benha University, Egypt, in 2007 and 2008 seasons, to determine the effect of two bacterial inoculation (uninoculation and inoculation with a mixture of Azot $+A z o s$ ) and seven $\mathrm{N}$ fertilizer rates (zero, $60 \mathrm{~kg} \mathrm{M}, 120 \mathrm{~kg} \mathrm{M}$, $60 \mathrm{~kg} \mathrm{O}, 120 \mathrm{~kg} \mathrm{O}, 30 \mathrm{~kg} \mathrm{M}+30 \mathrm{~kg} \mathrm{O}$ and $60 \mathrm{~kg} \mathrm{M}+60 \mathrm{~kg} \mathrm{O} / \mathrm{fed})$ on yield and yield components of two maize hybrids (S.C30k8 and S.C30k9). The most important results which were obtained from this study were as follows:

The difference between two maize hybrids was significant on ear diameter, No. of rows ear ${ }^{-1}$, weight of grains ear ${ }^{-1}$, 100-grain weight, shelling $\%$, grain yield plant $^{-1}$ and feddan ${ }^{-1}$ in combined analysis. Maize hybrid S.C. 30k9 gave the highest means values of the above characters.

Bacterial inoculation with a mixture of Azot+Azos affected significantly ear length, No. of rows ear ${ }^{-1}$, No of grains row ${ }^{-1}$, ear weight, weight of grains ear ${ }^{-1}$ and grain yield plant ${ }^{-1}$ in combined analysis.

Ear length, ear diameter, No. of rows ear ${ }^{-1}$, No of grains row ${ }^{-1}$, ear weight, weight of grains ear ${ }^{-1}, 100$-grain weight, shelling $\%$, grain yield plant $^{-1}$ and feddan ${ }^{-1}$ in combined analysis were significantly increased by increasing $\mathrm{N}$ fertilizer rates. Application of $120 \mathrm{~kg} \mathrm{M} / \mathrm{fed}$ or $60 \mathrm{~kg}$ $\mathrm{M}+60 \mathrm{~kg} \mathrm{O} / \mathrm{fed}$ gave the highest values of the above characters.

Effect of the interaction between maize hybrids and bacterial inoculation was significant on ear diameter and No. of rows ear ${ }^{-1}$ and the interaction between maize hybrids and $\mathrm{N}$ fertilizer rates was significant on ear length, ear diameter, No. of rows ear ${ }^{-1}$, No of grains row $^{-1}$, shelling\% and grain yield feddan ${ }^{-1}$, as well as the interaction between bacterial inoculation and $\mathrm{N}$ fertilizer rates was significant on ear diameter, No. of rows ear ${ }^{-1}$ and No of grains row ${ }^{-}$, while the interaction between maize hybrids, bacterial inoculation and $\mathrm{N}$ fertilizer rates was significant on ear diameter, No. of rows ear ${ }^{-1}$ and 100 -grain weight in combined analysis.

Key words: Maize hybrids, Inoculation, $N$ organic \& inorganic, Yield and Yield components.

\section{INTRODUCTION}

Maize (Zea mays L.) is one of the most important cereal crops in Egypt and the world. Maize is still a major traditional food and feed crop in many regions. Furthermore, the grain is a key industrial raw material for very diverse purposes. In Egypt great attention has been paid to increase its total production. This could be achieved by using high yielding cultivars, bacterial inoculation and fertilization. In this connection, maize cultivars differ in grain

Fayoum J. Agric. Res. \& Dev., Vol.23, No.1,(B). January, 2009 
yield and yield components as reported by El-Bana (2001); El-Wakil (2002); Hamed (2003); El-Aref et al (2004); Nofal et al (2005); Moser et al (2006); Atta (2007) and Hassan et al (2008).

Inoculated maize grains with Azotobacter or Azospirillum or mixture increased yield and yield components of maize as reported by Metwally et al (2007); Aly et al (2008) and Gholami et al (2009).

With regard to yield and yield components of maize were positively affected by increasing the rate of nitrogen (mineral and organic or mineral + organic) fertilizer as reported by El-Banna and Gomaa (2000); Abd El-All (2002); Saleh and Nawar (2003); Suleiman (2004); Abdel-Hameed (2005); Bader and Othman (2006); El-Maihy (2007); Shisanya et al (2008) and Ayoola and Makinde (2009).

The aim of this investigation was to study the effect of bacterial inoculation with a mixture of Azot $+A z o s$ and nitrogen fertilization (mineral and organic or mineral + organic) on yield and yield components of two maize hybrids.

\section{MATERIALS AND METHODS}

This investigation was conducted at the Agricultural Research and Experimental Center of the Faculty of Agriculture, Moshtohor, Kalubia Governorate, Benha University, Egypt, in 2007 and 2008 seasons, to study the effect of two bacterial inoculation [noninoculation (Nonin.), inoculation (Inoc.) with a mixture of Azotobacter (Azot) +Azospirillum (Azos)] and seven $\mathrm{N}$ fertilizer rates[zero, $60 \mathrm{~kg} \mathrm{~N}$ mineral $(60 \mathrm{~kg} \mathrm{M}), 120 \mathrm{~kg} \mathrm{~N}$ mineral $(120 \mathrm{~kg}$ $\mathrm{M}), 60 \mathrm{~kg} \mathrm{~N}$ organic $(60 \mathrm{~kg} \mathrm{O}), 120 \mathrm{~kg} \mathrm{~N}$ organic $(120 \mathrm{~kg} \mathrm{O}), 30 \mathrm{~kg} \mathrm{~N}$ mineral $(30 \mathrm{~kg} \mathrm{M})+30 \mathrm{~kg} \mathrm{~N}$ organic $(30 \mathrm{~kg} \mathrm{O})$ and $60 \mathrm{~kg} \mathrm{~N}$ mineral $(60 \mathrm{~kg} \mathrm{M})+60$ $\mathrm{kg} \mathrm{N}$ organic $(60 \mathrm{~kg} \mathrm{O}) / \mathrm{fed}]$ on yield and yield components for two maize hybrids[Single cross 30k8(S.C30k8) and Single cross 30k9(S.C30k9)].

The soil type was clay with $\mathrm{pH}$ value of 8.06 and 8.02 , organic mater was 1.91 and $1.98 \%$, total $\mathrm{N}$ was 0.14 and $0.12 \%$ in the first and second growing seasons, respectively. The experimental sites were preceded by wheat in the two seasons. Efficient strains of nitrogen fixers bacteria namely, Azotobacter chroococcum and Azospirillum brasilense supplied by the Microbiology Department, Soil, Water, and Environment Research Institute, ARC, Giza, Egypt. Maize hybrids namely S.C.30K8 and S.C.30K9 were developed by Pioneer Company. Organic fertilizer in the form of farmyard manure (FYM) whose chemical composition $\mathrm{pH}$ value of 7.80 and 7.98 , organic mater was 26.89 and $28.28 \%$, total $\mathrm{N}$ was 0.98 and $0.94 \%$ and $\mathrm{C} / \mathrm{N}$ ratio was $16: 1$ and 17:1 in the first and second growing seasons, respectively. The manure was applied during soil preparation before sowing. While, the rates of the mineral $\mathrm{N}$ fertilizer in the form of urea $46 \% \mathrm{~N}$ were added at two equal doses, the first dose after thinning and before the first irrigation and the second dose at before the second irrigation in both seasons.

A spilt plot design with three replications was used in each trial. The four treatments of the combinations between two maize hybrids and two bacterial inoculations were allocated with main plots and seven treatments for nitrogen fertilizer rates were randomly in the sub plots. Each sub-sub plot was $10.5 \mathrm{~m}^{2}$ (1/400 fed) consisting of 5 ridges, $3.5 \mathrm{~m}$ long and $70 \mathrm{~cm}$ width while, the distance between plants was $25 \mathrm{~cm}$.

At planting, super phosphate (15.5\%), at a rate of $30 \mathrm{~kg} \mathrm{P}_{2} \mathrm{O}_{5} / \mathrm{fad}$ was applied. Maize grains were inoculated with a mixture of Azot+Azos

Fayoum J. Agric. Res. \& Dev., Vol.23, No.1,(B). January, 2009 
immediately at planting where the adhesive glue material was added to $500 \mathrm{ml}$ mild hot water, splashed on grains and then bacterial were added, well mixed with grains and air dried for adhesion. Maize grains were planting on $28^{\text {th }}$ and $18^{\text {th }}$ May in the first and second seasons, respectively. All recommended cultural practices for the region were followed in both seasons.

At harvest ten plants were taken at random from each sub-plot to determine ear length $(\mathrm{cm})$, ear diameter $(\mathrm{cm})$, No. of rows ear ${ }^{-1}$, No. of grains row $^{-1}$, ear weight $(\mathrm{g})$, weight of grains ear ${ }^{-1}(\mathrm{~g})$, 100-grain weight $(\mathrm{g})$, shelling percentage and grain yield plant ${ }^{-1}(\mathrm{~g})$. Grain yield feddan ${ }^{-1}(\mathrm{~kg})$ was determined on the whole sub plot basis. The grain yield was adjusted to $15.5 \%$ moisture content.

Data of the experiments were statistically analyzed according to Gomez and Gomez (1984). L.S.D test at 0.05 level of probability was used to compare between means.

\section{RESULTS AND DISCUSSION}

Analyses of variances for all traits in each season as well as the combined analysis are presented in Table (1). Test of homogeneity revealed that the error variance for the two seasons were homogenous, therefore combined analysis was processed. Year's mean squares were not significant for all the studied traits except for ear length, 100-grains weight and grain yield feddan ${ }^{-1}$ were significant. The hybrids mean squares were significant for all traits in both seasons as well as the combined data except ear length, No. of grains row $^{-1}$, shelling\% and grain yield feddan ${ }^{-1}$ in the first season and No. of rows ear $^{-1}$, No. of grains row ${ }^{-1}$, ear weight and grain yield plant $^{-1}$ in the second season as well as ear length, No. of grains row $^{-1}$ and ear weight in the combined analysis. The bacterial inoculation mean squares were significant for all traits in both seasons as well as the combined data except ear length, ear diameter and grain yield feddan ${ }^{-1}$ in the first season and ear diameter, No. of rows ear ${ }^{-1}$, ear weight, 100-grain weight, shelling\%, grain yield plant ${ }^{-1}$ and grain yield feddan ${ }^{-1}$ in the second season as well as ear diameter, 100-grain weight, shelling\% and grain yield feddan ${ }^{-1}$ in the combined analysis. N fertilizer rates mean squares were highly significant for all studied traits in both seasons and combined analysis except 100-grain weight was significant only in the second season, while 100-grain weight and shelling\% were not significant in the first and second seasons, respectively. The interaction between years and hybrids mean squares was not significant for all of the studied characters except ear length. The interaction between years and inoculation mean squares was not significant for all of the studied characters except ear length and No. of rows ear ${ }^{-1}$. The interaction between years and $\mathrm{N}$ rates mean squares were not significant for all of the studied characters except ear diameter and No. of rows ear ${ }^{-1}$. The interaction between years, hybrids and inoculation mean squares were not significant for all of the studied characters except ear length. The interactions between years, hybrids and $\mathrm{N}$ rates mean squares were significant for ear weight and shelling\%. The interactions between years, inoculation and $\mathrm{N}$ rates mean squares were significant for ear diameter. Also, the interactions between years, hybrids, inoculation and $\mathrm{N}$ rates mean squares were significant for ear diameter.

Fayoum J. Agric. Res. \& Dev., Vol.23, No.1,(B). January, 2009 
Table 1

Fayoum J. Agric. Res. \& Dev., Vol.23, No.1,(B). January, 2009 
1- Effect of hybrids, inoculation and $N$ fertilizer rates on yield and its components of maize:

\section{1- Varietal differences.}

Data in Table (2) show effect of the varietal differences on yield and yield components of maize in combined analysis. Ear diameter, No. of rows ear ${ }^{-1}$, weight of grains ear ${ }^{-1}, 100$-grain weight, shelling percentage, grain yield plant 1 and grain yield feddan ${ }^{-1}$ of maize were significantly affected by the two maize hybrids under study. Maize hybrid S.C. 30k9 gave higher mean values of the above mentioned parameters. On the other hand, the difference between two maize hybrids was not significant on ear length, No. of grains row $^{-1}$ and ear weight. These differences may be due to the genetical differences between the two studied maize hybrids. Similar results were obtained by El-Bana (2001); El-Wakil (2002); Hamed (2003); El-Aref et al. (2004); Nofal et al (2005); Moser et al (2006); Atta (2007) and Hassan et al (2008).

\section{2- Effect of the bacterial inoculation.}

Maize ear length, No. of rows ear ${ }^{-1}$, No. of grains row $^{-1}$, ear weight, weight of grains ear ${ }^{-1}$ and grain yield plant $^{-1}$ of maize were significantly increased by bacterial inoculation in combined analysis as shown in Table (2). Ear length, No. of rows ear ${ }^{-1}$, No. of grains row $^{-1}$, ear weight, weight of grains ear $^{-1}$ and grain yield plant ${ }^{-1}$ increased with the inoculation a mixture of Azot + Azos by $2.50,1.44,6.06,2.38,2.29$ and $5.85 \%$ compared to noninoculated plants, respectively. On the other hand, ear diameter, 100-grain weight, shelling\% and grain yield feddan ${ }^{-1}$ were not significantly affected by bacterial inoculation in combined analysis. These microorganisms may produce some biological activities substances which improve plant growth. Similar results were obtained by Metwally et al (2007); Aly et al (2008) and Gholami et al (2009).

\section{3- Effect of $\mathbf{N}$ fertilizer rates.}

Maize ear length, ear diameter, No. of rows ear $^{-1}$, No. of grains row $^{-1}$, ear weight, weight of grains ear ${ }^{-1}, 100$-grain weight, shelling $\%$, grain yield plant ${ }^{-1}$ and grain yield feddan ${ }^{-1}$ were significantly increased by increasing $\mathrm{N}$ fertilizer rate in the combined analysis as shown in Table(2). Application of $120 \mathrm{~kg}$ $\mathrm{M} / \mathrm{fed}$ in the mineral form or $60 \mathrm{~kg} \mathrm{M}+60 \mathrm{~kg} \mathrm{O} / \mathrm{fed}$ gave higher values for the above mentioned parameters. Application of $\mathrm{N}$ rate $120 \mathrm{M} / \mathrm{fed}$ and $60 \mathrm{~kg}$ $\mathrm{M}+60 \mathrm{~kg} \mathrm{O} / \mathrm{fed}$ significantly increased ear length, ear diameter, No. of rows ear $^{-1}$, No. of grains row ${ }^{-1}$, ear weight, weight of grains ear ${ }^{-1}, 100$-grain weight, shelling \%, grain yield plant ${ }^{-1}$ and grain yield feddan ${ }^{-1}$ by 18.22 and $14.95 \%$, 27.71 and $23.61 \%, 12.18$ and $10.12 \%, 27.83$ and $23.22 \%, 24.35$ and $17.90 \%$, 35.10 and $26.94 \%, 8.38$ and $5.48 \%, 6.80$ and $5.99 \%, 85.00$ and $62.61 \%$ and 57.13 and $53.36 \%$, respectively compared with the zero N/fed. The increases in yield and components may be due to the increases in the growth characters and indirectly affected by $\mathrm{N}$ general functions in plant. Furthermore, the increase in grain yield/fed is attributed mainly to the increases in yield components. Similar results were obtained by El-Bana and Gomaa (2000); Abd El-All (2002); Saleh and Nawar (2003); Suleiman (2004); AbdelHameed (2005); Bader and Othman (2006); El-Maihy (2007); Shisanya $e t$ al (2008) and Ayoola and Makinde (2009).

Fayoum J. Agric. Res. \& Dev., Vol.23, No.1,(B). January, 2009 
Table 2

Fayoum J. Agric. Res. \& Dev., Vol.23, No.1,(B). January, 2009 
3. Interactions effect:

Effect of the interaction between maize hybrids and bacterial inoculation was significant on ear diameter and No. of rows ear $^{-1}$ (Table 3a). S.C. 30k9 under inoculation with a mixture of Azot + Azos gave higher $\mathrm{P}$ value than the S.C. $30 \mathrm{k} 8$.

Table (3a): Effect of the interaction between maize hybrid and bacterial inoculation on ear diameter and number of row ear $^{-1}$ of maize (over the combined analysis)

\begin{tabular}{|c|c|c|c|}
\hline $\begin{array}{c}\text { Maize } \\
\text { hybrids }\end{array}$ & $\begin{array}{c}\text { Bacterial } \\
\text { inoculation }\end{array}$ & $\begin{array}{c}\text { Ear diameter } \\
(\mathbf{c m})\end{array}$ & $\begin{array}{c}\text { Number of } \\
\text { rows ear }\end{array}$ \\
\hline \multirow{2}{*}{ S.C. 30K8 } & Nonin. & 4.74 & 13.80 \\
\cline { 2 - 4 } & Inoc. & 4.90 & 13.92 \\
\hline \multirow{2}{*}{ S.C. 30K9 } & Nonin. & 4.831 & 13.89 \\
\cline { 2 - 4 } & Inoc. & 4.98 & 14.17 \\
\hline \multicolumn{2}{|r}{ L.S.D at 5\% } & $\mathbf{0 . 0 5}$ & $\mathbf{0 . 0 6}$ \\
\hline
\end{tabular}

The effect of the interaction between maize hybrids and $\mathrm{N}$ fertilizer rates was significant on ear length, ear diameter, No. of rows ear ${ }^{-1}$, No. of grains row $^{-1}$, shelling\% and grain yield feddan ${ }^{-1}$ (Table 3b). Maize hybrid S.C 30k9 under $120 \mathrm{~kg} \mathrm{M} / \mathrm{fed}$ gave the highest values of the above mentioned characters except No. of grains row ${ }^{-1}$ S.C $30 \mathrm{k} 8$ under the same $\mathrm{N}$ rate gave the highest value of this trait.

Table (3b): Effect of the interaction between maize hybrids and $\mathbf{N}$ fertilizer rates on ear length, ear diameter, No. of rows ear $^{-1}$, No. of grains row ${ }^{-1}$, shelling $\%$ and grain yield fed ${ }^{-1}$ of maize (over the combined analysis)

\begin{tabular}{|c|c|c|c|c|c|c|c|}
\hline 量 & $\begin{array}{l}\text { N rates } \\
(\mathrm{kg} / \mathrm{fed})\end{array}$ & $\begin{array}{l}\text { Ear } \\
\text { length } \\
(\mathrm{cm})\end{array}$ & $\begin{array}{c}\text { Ear } \\
\text { diameter } \\
(\mathbf{c m})\end{array}$ & $\begin{array}{c}\text { No. of } \\
\text { rows ear }\end{array}$ & $\begin{array}{l}\text { No. of } \\
\text { grains } \\
\text { row }^{-1}\end{array}$ & $\begin{array}{c}\text { Shelling } \\
\%\end{array}$ & $\begin{array}{c}\text { Grain } \\
\text { yield } \\
\text { fed }^{-1}(\mathrm{~kg})\end{array}$ \\
\hline \multirow{7}{*}{ 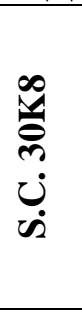 } & Zero & TV.VT & $\varepsilon .1 \pi$ & $1 T .4$ & rq.r & 19.10 & TrTI.乏 \\
\hline & $\begin{array}{ll}60 & M \\
\end{array}$ & 19.70 & $\sum . V 1$ & $1 \Gamma . \leqslant \wedge$ & $\leqslant 7.1$. & Aะ.77 & r997.7 \\
\hline & $120 \mathrm{M}$ & Y.Y. & $0 . Y$. & $1 \leqslant .00$ & $01 . V \cdot$ & $\Lambda \varepsilon .{ }^{\prime}$ & $01 \cdot V . r$ \\
\hline & 600 & $19.1 \leqslant$ & $\varepsilon .0 \%$ & 11.09 & 50.17 & $1 \leqslant .91$ & rATO. \\
\hline & 1200 & $19 . V \varepsilon$ & $\leqslant .10$ & 14.94 & $\Sigma V . \leqslant 7$ & $10 . \leqslant 1$ & $\varepsilon .9 \varepsilon . V$ \\
\hline & $30 \mathrm{M}+30 \mathrm{O}$ & $r \cdot . \cdot \Lambda$ & 0.19 & $1 \leqslant .10$ & $\varepsilon \wedge . \cdot 1$ & $\Lambda V_{.} .$. & $\varepsilon .09 . \mathrm{V}$ \\
\hline & $60 \mathrm{M}+60 \mathrm{O}$ & $Y \cdot .0 Y$ & 0.11 & $1 \varepsilon . \mu T$ & $\sum \Lambda . \vee \cdot$ & Ar.q1 & $\sum 9 \vee \% . \cdot$ \\
\hline \multirow{7}{*}{ نे } & Zero & $11 . r 4$ & 5.17 & IT.YT & $\Sigma 1 . \Gamma V$ & $\Delta \Gamma . . \cdot$ & $r \leqslant 0 Y .0$ \\
\hline & $\begin{array}{ll}60 & M \\
\end{array}$ & 19.0 & $\varepsilon . \vee T$ & $\mid \pi .71$ & $\varepsilon 0 . \varepsilon V$ & NV.YO & $\varepsilon 1 \leqslant 9 . \xi$ \\
\hline & $120 \mathrm{M}$ & $r 1 . \leqslant T$ & $0 . \varepsilon$ & $1 \leq .91$ & $01 . \leqslant 0$ & $19 . \cdot 1$ & $0 \leqslant \leqslant Y . Y$ \\
\hline & 600 & 19.11 & $\sum . \vee \wedge$ & 15.70 & $\sum 7.4$. & AY.ro & r4r9. \\
\hline & 1200 & 19.09 & $\varepsilon .94$ & $1 \% .94$ & $\varepsilon \vee . \vee 0$ & 10.91 & $\sum 101.1$ \\
\hline & $30 \mathrm{M}+30 \mathrm{O}$ & $Y \cdot . T \leqslant$ & $0.1 \varepsilon$ & $1 \leqslant . Y \wedge$ & $\leqslant 9.0$. & A7.Vo & $r q \cdot \varepsilon . r$ \\
\hline & $60 \mathrm{M}+60 \mathrm{O}$ & $T \cdot .9 V$ & 0.10 & $1 \leq .7$. & $0 . . V Y$ & $1 \Lambda .01$ & OTYT.Y \\
\hline \multicolumn{2}{|c|}{ L.S.D at $5 \%$} & 0.39 & 0.11 & 0.16 & 1.13 & 3.55 & 278.1 \\
\hline
\end{tabular}

Effect of the interaction between bacterial inoculation and $\mathrm{N}$ fertilizer rates was significant on ear diameter, No. of rows ear ${ }^{-1}$ and No. of grains row $^{-1}$ of maize (Table 3c). Inoculation with a mixture of Azot+Azos under $120 \mathrm{~kg} \mathrm{M}$

Fayoum J. Agric. Res. \& Dev., Vol.23, No.1,(B). January, 2009 
/fed or $60 \mathrm{M}+60 \mathrm{O} \mathrm{kg} / \mathrm{fed}$ gave the highest values of the above mentioned characters.

Effect of the interaction between maize hybrids, bacterial inoculation and $\mathrm{N}$ fertilizer rates was significant on ear diameter, No. of rows ear ${ }^{-1}$ and 100grain weight (Table 3d). Maize hybrid S.C. 30k9 and inoculation with mixture of Azot+Azos under $120 \mathrm{~kg} \mathrm{M} / \mathrm{fed}$ gave the highest values of above characters.

Table (3c): Effect of the interaction between bacterial inoculation and $\mathrm{N}$ fertilizer rates on ear diameter, No. of rows ear $^{-1}$ and No. of grains row ${ }^{-1}$ of maize (over the combined analysis)

\begin{tabular}{|c|c|c|c|c|c|c|}
\hline \multirow{2}{*}{$\begin{array}{l}\text { Bacterial inoculation } \\
\text { N rates }(\mathrm{kg} / \mathrm{fed})\end{array}$} & Nonin. & Inoc. & Nonin. & Inoc. & Nonin. & Inoc. \\
\hline & \multicolumn{2}{|c|}{ Ear diameter $(\mathrm{cm})$} & \multicolumn{2}{|c|}{ No. of rows ear } & \multicolumn{2}{|c|}{ No. of grains row ${ }^{-1}$} \\
\hline Zero & $\varepsilon . \varepsilon^{2}$ & E.YO & $1 \% .1$. & 15.17 & 49.87 & $\varepsilon \cdot .9 Y$ \\
\hline $60 M$ & $\varepsilon . \wedge$. & $\varepsilon . T V$ & 14.01 & $1 \pi .01$ & $\varepsilon Y . V Y$ & $\varepsilon \wedge . \wedge$. \\
\hline $120 \mathrm{M}$ & $0 . \mu^{\mu}$ & $0 . \mu v$ & $1 \leqslant . \vee$. & $1 \varepsilon .17$ & $01 . r$. & 01.10 \\
\hline 600 & \{.71 & $\varepsilon . \vee \cdot$ & 11.0 & $1 \% . V T$ & $\varepsilon \varepsilon .1 V$ & $\sum Y . Y$. \\
\hline 1200 & $\varepsilon .9$. & $\varepsilon . \wedge \mathrm{V}$ & $1 \Gamma . \lambda 1$ & $1 \varepsilon .0$ & $\sum 0 . V_{0}$ & $\{9 . \leqslant 7$ \\
\hline $30 \mathrm{M}+30 \mathrm{O}$ & $0.1 \mathrm{~V}$ & $0 . \mathrm{V}$ & $1 \varepsilon .1$ & $1 \varepsilon . r_{0}$ & $\varepsilon v_{.} \varepsilon \cdot$ & $0 . .11$ \\
\hline $60 \mathrm{M}+60 \mathrm{O}$ & 0.10 & 0.1. & 15.17 & $1 \varepsilon .17$ & $\sum \Lambda . T Y$ & $0 . . \wedge$. \\
\hline L.S.D at 5\% & \multicolumn{2}{|c|}{0.11} & \multicolumn{2}{|c|}{0.16} & \multicolumn{2}{|c|}{1.13} \\
\hline
\end{tabular}

Table (3d): Effect of the interaction between maize hybrids, bacterial inoculation and $\mathbf{N}$ fertilizer rates on ear diameter, No. of rows ear ${ }^{-1}$ and 100grain weight of maize (over the combined analysis)

\begin{tabular}{|c|c|c|c|c|c|c|c|}
\hline \multirow{2}{*}{\multicolumn{2}{|c|}{\begin{tabular}{|l|} 
Maize hybrids \\
Treatments \\
\end{tabular}}} & S.C 30K8 & $\begin{array}{c}\text { S.C } \\
\text { 30K9 }\end{array}$ & S.C 30K8 & S.C30K9 & S.C30K8 & S.C30K9 \\
\hline & & \multicolumn{2}{|c|}{ Ear diameter $(\mathrm{cm})$} & \multicolumn{2}{|c|}{ No. of rows ear ${ }^{-1}$} & \multicolumn{2}{|c|}{ 100-grain weight (g) } \\
\hline \multirow{7}{*}{ 节 } & Zero & $r .97$ & £.11 & $1 \pi .$. & IT.Y. & TY.AV & 49.07 \\
\hline & $\begin{array}{ll}60 & M \\
\end{array}$ & $\sum .71$ & $\varepsilon .94$ & $1 \pi . \leq 7$ & 15.07 & M.T. & r9.0r \\
\hline & $120 \mathrm{M}$ & 0.11 & $0.4 \Lambda$ & $1 \varepsilon . V \mu$ & $1 \leqslant . \wedge$. & TV.OV & $\varepsilon 1 . \cdot 1$ \\
\hline & 600 & E.rT & ะ.9. & $11 . \leqslant 0$ & 15.07 & To.rv & 49.01 \\
\hline & 1200 & $\varepsilon . V \mu$ & 0.11 & $11 . \wedge 7$ & $15 . V 4$ & 47.4 & $r \Lambda . \leqslant 9$ \\
\hline & $30 \mathrm{M}+30 \mathrm{O}$ & $0 . Y^{\mu}$ & $0 . Y \Lambda$ & $1 \leqslant .1$. & $1 \leqslant .9$ & $r V . \leqslant 7$ & r. . YO \\
\hline & $60 \mathrm{M}+60 \mathrm{O}$ & 0.11 & 0.17 & $1 \varepsilon .4$ & I ₹.r. & 47.70 & 49.17 \\
\hline \multirow{7}{*}{$\stackrel{\Xi}{\Xi}$} & Zero & E.r. & ¿.r! & 14.7 & $1 \% . r 4$ & ro. $\leqslant 0$ & $r v .1 T$ \\
\hline & $60 M$ & 纟. . & ะ.7. & $15.0 \cdot$ & 15.74 & $r v .1 \leq$ & $r \Lambda_{.} \cdot v$ \\
\hline & $120 \mathrm{M}$ & $0 . \pi$ & $0 . \varepsilon 1$ & $1 \leq .24$ & 10.4 & $r v .91$ & $\varepsilon 1.01$ \\
\hline & 600 & 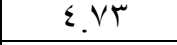 & $\varepsilon .77$ & $1 \% . V \mu$ & IT.VT & r.. 29 & M.. . \\
\hline & 1200 & $\varepsilon .97$ & ¿.YA & $1 \leq .$. & 1 I.1. & $r 0.07$ & $r \Lambda . Y T$ \\
\hline & $30 \mathrm{M}+30 \mathrm{O}$ & 0.10 & $0 .$. & IE.Y. & $1 \leqslant .0$. & ro.1. & $\varepsilon \cdot .7 \pi$ \\
\hline & $60 \mathrm{M}+60 \mathrm{O}$ & 0.17 & 0.11 & $1 \leq .74$ & $1 \leqslant .9$. & rV. $\varepsilon q$ & $\varepsilon \cdot .7 \varepsilon$ \\
\hline \multicolumn{2}{|c|}{ at $5 \%$} & \multicolumn{2}{|c|}{0.15} & \multicolumn{2}{|c|}{0.23} & \multicolumn{2}{|c|}{2.01} \\
\hline
\end{tabular}

M=Mineral $\quad$ O=Organic

Fayoum J. Agric. Res. \& Dev., Vol.23, No.1,(B). January, 2009 


\section{REFERENCES}

Abd El-All, A.M. (2002): Effect of preceding crops, organic and mineral nitrogen and plant density on productivity of maize plant. J. Agric. Sci., Mansoura Univ., 27 (12):8093-8105.

Abdel-Hameed, I.M. (2005): Effect of sources and levels of nitrogen fertilization on productivity of maize. Proc. $11^{\text {th }}$ Conf. of Agronomy, Agron. Dept., Fac. Agric., Assiut Univ., Nov., I: 171 - 187.

Aly, M.H.; Soudi, A.M. and Ashmaye, S.H. (2008): The usage of biofertilizer to minimize the mineral fertilizer for sweet sorghum. Egypt J. Appl. Sci., 23 (2B): 486-499.

Atta, Y.I. (2007): Improving growth, yield and water productivity of some maize cultivars by new planting method. Egypt J. Appl. Sci., 22(11): 1-16.

Ayoola O.T. and E.A. Makinde (2009): Maize growth, yield and soil nutrient changes with N-enriched organic fertilizers. African J. Food, Agric., Nutrition and Development 9(1) 580-592.

Bader, M.A. and Sanaa A. Othman (2006): Effect of plant density, organic manure, bio and mineral nitrogen fertilizers on maize growth and yield and soil fertility. Ann. of Agric. Sc., Moshtohor, Egypt, 44 (1): 75-88.

El-Aref, Kh. A.O.; Abo El-Hamed, A.S. and Abo El-Wafa, A.M. (2004): Response of some maize hybrids to nitrogen and potassium fertilization levels. J. Agric. Sci. Mansoura Univ., 29(11): 6063-6070.

El-Bana, A.Y.A. (2001): Effect of nitrogen fertilization and stripping leaves on yield and yield attributes of tow maize (Zea mays L.) hybrids. Zagazig J. Agric. Res., 28 (3): 579-596.

El-Bana, A.Y.A. and M.A. Gomaa (2000): Effect of N and K fertilization on maize grown in different populations under newly reclaimed sandy soil. Zagazig J. Agric. Res., 27 (5): 1179-1190.

El-Maihy, Amira A.E. (2007): Evaluation of some crop successions of main crops under different fertilization levels. M. Sc. Thesis, Fac. Agric., Benha Univ., Egypt.

El-Wakil, N.M.H. (2002): Response of some cultivars of maize to plant density and nitrogen fertilization. M.Sc., Thesis, Fac., Agric., Moshtohor, Zagazig Univ., Egypt.

Gholami, A.; S. Shahsavani, and S. Nezarat (2009): The effect of plant growth promoting rhizobacteria (pgpr)on germination, seedling growth and yield of maize. Inter. J. Bio. and Life Sciences, 1(1):35-40.

Gomez, K.A. and A.A. Gomez (1984): Statistical procedures for agricultural research. 2nd, (ed.). John Wiley and Sons, NY, U.S.A.

Hamed, M.F (2003): Performance of two maize hybrids under irrigation intervals and ethryl treatments. Annals of Agric., Sc., Moshtohor, 41(2):669-678.

Hassan, M.M.M.; M.A.M. El-Ghonemy and R.S.H. Aly (2008): Response of some maize single cross hybrids to plant density under different Egyptian environmental conditions. Minufia J. Agric. Res., 33(2): 427-443.

Metwally, A. A.; M. M. Shafik; M. Fayez and S. A. Safina. (2007): Effect of nitrogen fertilization and diazotroph inoculation on yield of solid intercropped maize with soybean. J. Agric. Sci. Mansoura Univ., 32(6): 4207-4215.

Moser, S.B.; B. Feil ; S. Jampatong and P. Stamp (2006): Effects of preanthesis drought, nitrogen fertilizer rate, and variety on grain yield, yield components, and harvest index of tropical maize. Agric. Water Manage., 81: $41-58$.

Fayoum J. Agric. Res. \& Dev., Vol.23, No.1,(B). January, 2009 
Nofal, F.A.; G.M.A. Mahgoub and R.I. Faisal (2005): Nitrogen use efficiency of some maize hybrids under different rates of nitrogen fertilizer. Egypt. J. Appl. Sci. 20(4): 145-147.

Saleh, S.A. and F.R.R. Nawar (2003): Effect of mineral and organic manure fertilizers on maize productivity in reclaimed land. J. Adv. Agric. Res. (Fac. Agric. Saba Basha).,8 (1): 59- 68.

Shisanya, C.A.; Monica W. Mucheru; D.N. Mugendi; J.B. Kung'u (2008): Effect of organic and inorganic nutrient sources on soil mineral nitrogen and maize yields in central highlands of Kenya. Soil \& Tillage Research, doi:10.1016/j.still.5-16

Suleiman, M.M. (2004): Effect of mineral and organic fertilization and plant density on growth and yield of corn in sandy soil. Ph. D. Thesis. Fac. Agric., Cairo. Univ., Egypt.

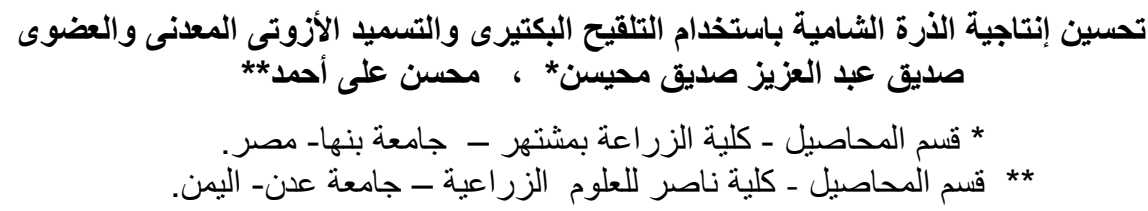

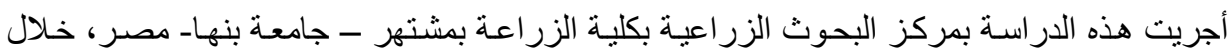

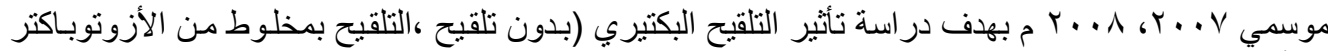

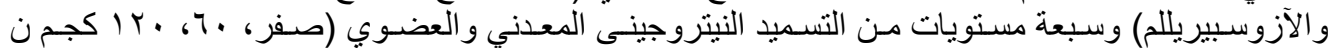

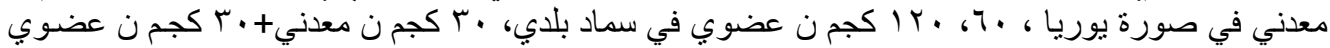

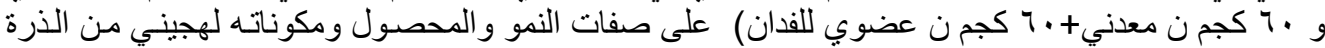

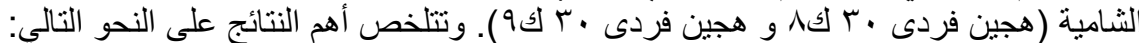

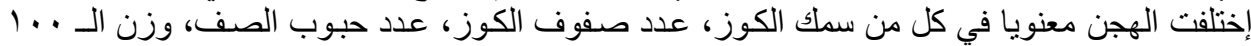

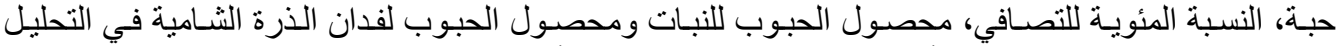

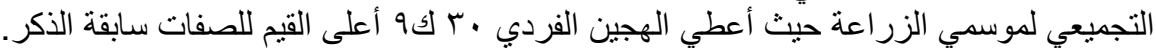

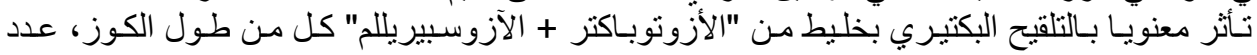

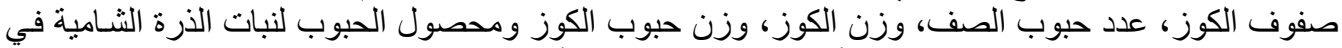

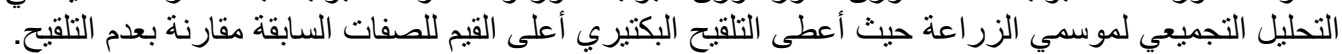

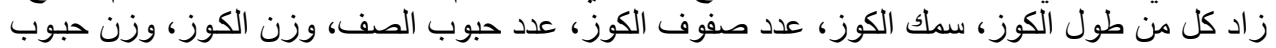

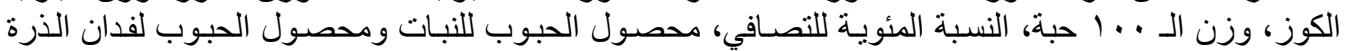

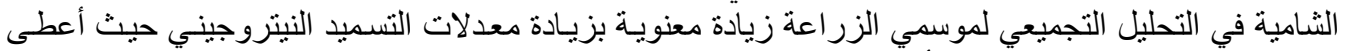

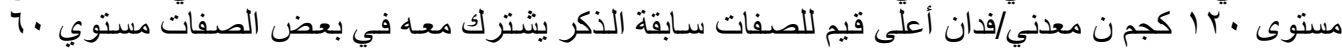

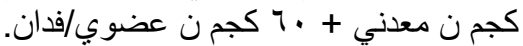

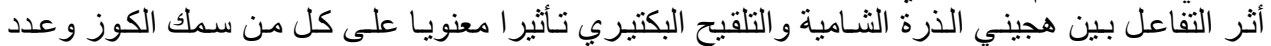

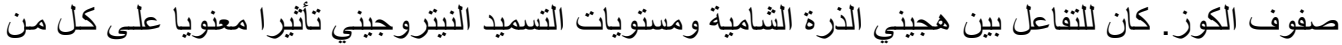

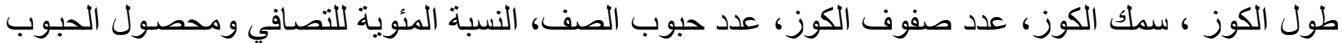

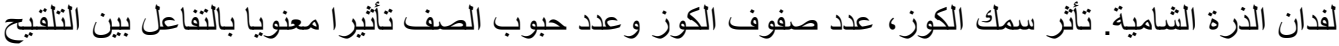
البكتيري ومستويات التسميد النيتروجيني.

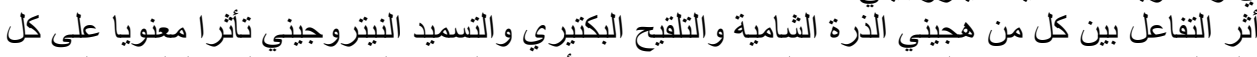

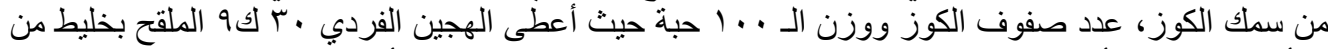

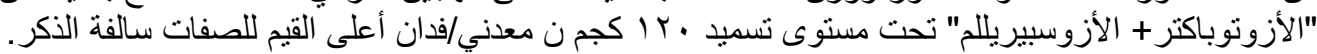

Fayoum J. Agric. Res. \& Dev., Vol.23, No.1,(B). January, 2009 